\title{
Volatility Jump: The Effect of COVID-19 on Turkey Stock Market
}

\section{Oynaklık Sıçraması: COVID-19'un Türkiye Hisse Senedi Piyasası Üzerindeki Etkisi}

\author{
Oktay ÖZKAN a *
}

a Arş. Gör. Dr., Tokat Gaziosmanpaşa Üniversitesi, İktisadi ve İdari Bilimler Fakültesi, İşletme Bölümü, Tokat / TÜRKIYYE ORCID: 0000-0001-9419-8115

\section{A K A L E B İL G İ S İ \\ Makale Geçmişi: \\ Başvuru tarihi: 9 Temmuz 2020 \\ Kabul tarihi: 6 Ekim 2020}

\section{Anahtar Kelimeler:}

COVID-19,

Pandemi,

Gerçekleşen Oynaklık,

Hisse Senedi Piyasası,

Oynaklık Sıçraması

\section{A R T ICLE INFO}

Article History:

Received July 9, 2020

Accepted October 6, 2020

\section{Keywords:}

COVID-19,

Pandemic,

Realized Volatility,

Stock Market,

Volatility Jump

\section{ÖZ}

Bu çalışma Koronavirüs (COVID-19)'ün Türkiye hisse senedi piyasası üzerindeki etkisini incelemektedir. Bu amaç için, Borsa İstanbul'da işlem gören 23 birincil sektör endeksinin Haziran 2019 ile Temmuz 2020 arasındaki aylık gerçekleşen oynaklıkları hesaplanmıștır. Gerçekleșen oynaklık değerleri analiz edildikten sonra (1) COVID-19'un Türkiye'deki vakaların ortaya çıktığı ve hızla arttığı Mart 2020'de tüm sektör endekslerinde volatilite sıçramasına neden olduğu; (2) COVID-19 pandemisi döneminde en fazla oynaklık sıçramasının spor şirketlerinin hisselerinde görüldüğü, en az oynaklık sıçramasının ise sigorta firmalarının senetlerinde görüldüğ̈̈̈; (3) Mart 2020'den sonra bütün sektör endekslerinin gerçekleşen oynaklık değerlerinin normale döndüğü ve COVID-19'un Türkiye hisse senedi piyasası oynaklığına etkisinin kaybolduğu bulunmuştur. Bu sonuçlar diğer bir önemli oynaklık ölçütü olan GARCH-temelli oynaklık ile doğrulanmıştır. COVID-19'un Türkiye hisse senedi piyasasına etkisini ve piyasanın güncel durumunu gösteren bu çalışmanın, sadece yatırımcılar, portföy yöneticileri ve politika yapıcılar için değil aynı zamanda COVID-19'un ekonomik ve finansal etkilerini göstermek isteyen ekonomi ve finans alanındaki akademisyenler için de önemli çıkarımlar sağlayacağına inanılmaktadır.

\begin{abstract}
A B S T R A C T
This paper investigates the effect of Coronavirus (COVID-19) on Turkey stock market. For this purpose, montly realized volatilities of 23 primary sector indices traded on Borsa İstanbul are calculated for the period of June 2019 to July 2020. After analyzing realized volatility values, it is found that: (1) COVID-19 caused volatility jump for all sector indices in March 2020, when cases in Turkey appeared and increased rapidly; (2) While the most volatility jump occurred in stocks of sports companies during the period of the COVID-19 pandemic, the least volatility jump occurred in stocks of insurance firms; (3) After March 2020, realized volatility values back to normal for all sector indices and the effect of COVID-19 on Turkey stock market volatility has disappeared. These results are confirmed by another important volatility measure, namely, GARCH-based volatility. This paper showing the impact of COVID-19 on the Turkish stock market and the recent state of the markets is believed to provide important implications for not only investors, portfolio managers, and policymakers, but also for academics in economics and finance, who are all looking to demonstrate economic and financial effects of COVID-19.
\end{abstract}

\footnotetext{
* Sorumlu yazar/Corresponding author.

e-posta: oktay.ozkan@gop.edu.tr
} 


\section{EXTENDED ABSTRACT}

Aralık 2019 tarihinde Çin'in Hubei eyaletindeki Wuhan şehrinde ortaya çıkan Koronavirüs (COVID-19) hızlı bir şekilde Dünya genelinde birçok bölgeye yayılmıştır. Dünya Sağlı Örgütü 11 Mart 2020 tarihinde COVID-19’u küresel bir pandemi ilan etmiş ve ülkeleri COVID-19 salgınını kontrol etmek için ani ve katı önlemler almaya yöneltmiştir. Her ne kadar COVID-19 salgınına karşı ülkeler sıkı tedbirler alsa da, COVID19'un insanlar arasındaki yayılımı henüz durdurulamamıştır. 8 Temmuz 2020 tarihi itibari ile Dünya genelinde COVID-19 toplam 215 ülkede görülmüş, 11.973.641 vaka saptanmış ve 547.120 insan hayatını kaybetmiştir. Türkiye'de ise COVID-19'un ilk vakası 11 Mart 2020 tarihinde Türkiye Sağlık Bakanlığı tarafından duyurulmuştur. 11 Mart 2020 tarihinden 8 Temmuz 2020 tarihine kadar Türkiye'de toplam 207.897 vaka tespit edilmiş ve 5.260 kişi hayatını kaybetmiştir. Sadece insanların sağlığını etkilemekle kalmayan COVID-19, aynı zamanda ülke ekonomilerini de olumsuz bir şekilde etkilemiştir. Ülkelerin sınırlarını kısıtlaması ve kapatması, küresel ekonomik aktivitelerin yavaşlamasına neden olmuştur. En önemlisi şirketler, yatırımcılar ve tüketicilerde ortaya çıkan panik havası tüketim davranışlarını değiştirmiş ve finansal piyasalarda anomalilerin ortaya çıkmasına neden olmuştur. Ülkelerin finansal piyasaları da ortaya çıkan bu duruma hisse senedi endekslerinde meydana gelen düşüşlerle tepki göstermiştir.

COVID-19'un finansal ve ekonomik etkileri son zamanlarda literatürde araştırılmaya başlanmıştır. Alber (2020) COVID-19'un hisse senedi piyasaları üzerindeki etkilerini Çin, Fransa, Almanya, İtalya, İspanya ve ABD için araştırmış ve hisse senedi piyasası getirilerinin COVID-19 kümülatif vaka sayılarına daha fazla duyarlı olduğunu tespit etmiştir. Çalışmada ayrıca COVID-19'un İtalya ve ABD için hisse senedi piyasası getirileri üzerinde olumsuz bir etkisi olmadığı belirlenmiştir. Ayittey vd. (2020) ile Luo ve Tsang (2020) COVID-19'un Çin ve Dünya üzerindeki ekonomik etkilerini açıklamışlardır. Baker vd. (2020) ABD borsasının COVID-19'a tepkisini incelemişler ve COVID-19 nedeniyle ABD borsasının getiri oynaklığında sı̧̧rama olduğunu bulmuşlardır. Cinel (2020) COVID-19'un küresel makroekonomik etkilerini araştırmış ve bazı olası senaryolar ile COVID-19'un potansiyel küresel ekonomik maliyetlerini açıklamıştır. COVID-19'un Çin'in ticareti ve finansal piyasaları üzerindeki etkisi ampirik olarak Estrada vd. (2020) tarafından belirlenmiştir. Göker vd. (2020) COVID-19'un Türkiye'deki sektör endekslerinin getirileri üzerindeki etkisini analiz etmişler ve COVID-19 salgını sırasında spor, turizm ve ulaşım sektör endekslerinin getirilerinin diğer sektör endekslerinin getirilerinden daha fazla etkilendiğini bulmuşlardır. Günay (2020) COVID-19'un hisse senedi piyasaları üzerindeki etkisini Çin, İtalya, İspanya, Türkiye, İngiltere ve ABD örnekleminde araştırmış ve COVID-19'un yayılım etkileri nedeniyle Çin ve Türkiye borsaları arasındaki ilişkilerinin diğer borsalar arasındaki ilişkilerinden daha fazla arttığını belirlemiştir. Kılıç (2020) COVID-19'un Borsa İstanbul sektör getirileri üzerindeki etkisini incelemiş ve birçok sektörde COVID-19 nedeniyle negatif anormal getirilerin bulunduğunu belirlemiştir. McKibbin ve Fernando (2020) COVID-19'un küresel makroekonomik etkilerini yedi senaryo ile araştırmışlar ve COVID-19 salgınının küresel ekonomiyi sadece kısa vadede önemli ölçüde etkileyebileceğini ve COVID-19'un gelecekteki maliyetlerinin halk sağlığı sistemlerine daha fazla yatırım yaparak önlenebileceğini bildirmişlerdir. COVID-19'un Çin ve ABD finansal piyasaları üzerindeki etkisi ampirik olarak Sansa (2020) tarafından, Çin borsası üzerindeki etkileri ise Yan (2020) tarafından belirlenmiştir. Sarı ve Kartal (2020) COVID-19'un altın fiyatları ve VIX endeksi üzerindeki etkisini göstermişlerdir. Soylu (2020) COVID-19 nedeniyle Türkiye ekonomisindeki bazı makroekonomik göstergelerde meydana gelen değişimleri incelemiş ve COVID-19'un Türkiye ekonomisinde sektörel güven endekslerini, diş ticaret istatistiklerini, işgücü piyasasını, sanayi üretim endeksini ve turizm gelirlerini doğrudan etkilediğini belirlemiştir. Telek (2020) COVID-19 ölüm ve vakası sayısı ile dolar endeksi arasında eşbütünleşme ilişkisinin olduğunu ve COVID-19 vakalarında ve ölüm sayılarındaki pozitif şokların dolar endeksi ve altın ons fiyatı üzerinde şoklara neden olduğunu ortaya koymuştur. Zeren ve Hızarcı (2020) COVID-19'un borsalar üzerindeki olası etkilerini Çin, Fransa, Almanya, İtalya, Güney Kore ve İspanya için belirlemişlerdir.

Ulusal literatürde yer alan çalışmalar COVID-19'un Türkiye'deki hisse senetlerinin getirileri üzerindeki etkileri ile ilgili önemli bilgiler sağlamıştır. Fakat COVID-19'un Türkiye'deki hisse senetlerinin genellikle belirsizliğin bir ölçüsü olarak tanımlanan ve aynı zamanda sadece yatırım ve portföy yönetimi kararları için değil, aynı zamanda opsiyon fiyatlandırması ve finansal piyasa düzenlemesi için de en önemli göstergelerden bir tanesi olan oynaklıkları üzerindeki etkileri hakkında neredeyse hiçbir bilgi ulusal literatürde bulunamamışır. Bu eksikliği giderebilmek için gerçekleştirilen bu çalışmanın amacı, COVID-19 salgınının Türkiye hisse senedi piyasası üzerindeki etkisini finansal varlıkların oynaklıklarını belirleyebilmek için ampirik finans çalışmalarında sıklıkla kullanılan gerçekleşen oynaklık ile araştırmaktır.

Bu çalışmada, COVID-19 salgınının Türkiye hisse senedi piyasası üzerindeki etkisini belirleyebilmek için Borsa İstanbul'da işlem gören 23 birincil sektör endeksinin (Bankalar, Basit Metaller, Bilgi Teknolojileri, Elektrik, Finansallar, Gayrimenkul Yatırımları, Hizmet, Holding \& Yatırımlar, Kimyasal, Petrol \& Plastik, Leasing ve Faktöring, Metal Harici Mineral Ürünleri, Metal Ürünleri \& Makineler, Odun, Kağıt \& Bask1, Sanayi, Sigorta, Spor, Teknoloji, Tekstil \& Deri, Telekomünikasyon, Toptan Satış \& Perakende Ticaret, Turizm, Ulaştırma, Yiyecek \& İçecek) 7 Haziran 2019 ile 6 Temmuz 2020 tarihleri arasındaki (270 gözlem) günlük verileri kullanılmıştır. Sektör endekslerine ait günlük kapanış değerleri olarak elde edilen veriler öncelikle günlük getiri oranlarına çevrilmiştir. Sonraki adımda ise günlük getiri oranlarının karesi alındıktan sonra her ay içerisinde olan getiri oranlarının kareleri toplanarak her bir ay için gerçekleşen oynaklık değerleri hesaplanmıştır.

Her bir sektör için aylık olarak hesaplanan gerçekleşen oynaklık değerlerinin grafikleri incelendiğinde, Dünya Sağlık Örgütü' nün COVID-19'u küresel pandemi olarak ilan ettiği ve Türkiye'de ilk vakanın ortaya çıktığı dönem olan Mart 2020'de çalışma kapsamında kullanılan bütün sektör endekslerinde önemli ölçüde oynaklık sıçramaları tespit edilmiştir. \%15,7'lik oynaklık sıçraması ile COVID-19'dan en fazla etkilenen hisse senetleri spor sektörü içerisinde yer alan firmalara ait hisse senetleri olmuştur. COVID-19'dan en az etkilenen hisse senetleri ise \%2'lik oynaklık sıçraması ile sigorta sektörü içerisinde yer alan firmalara ait hisse senetleri olmuştur. Ayrıca Leasing ve Faktöring, Turizm, Bilgi Teknolojileri, Ulaşım ve Tekstil \& Deri sektörü içerisinde yer alan firmaların hisse senetleri diğer sektörlerde yer alan firmaların hisse senetlerine göre daha fazla oynaklık sıçraması göstermiş, diğer bir ifadeyle COVID-19'dan daha fazla etkilenmiştir. Mart 2020 tarihinden sonra ise çalışma kapsamındaki sektör endekslerinin gerçekleşen oynaklıkları normal seyrine dönmüş ve COVID-19'un Türkiye hisse senedi piyasasının oynaklığı üzerindeki etkisi ortadan kalkmıştır. Elde edilen bu sonuçlar literatürde oynaklık ölçümü için sıklıkla kullanılan GARCH-temelli oynaklık ile doğrulanmıştır. Her ne kadar COVID-19 için ikinci bir dalganın gelmesi beklense de Türkiye hisse senedi piyasasının ikinci dalgadan bu kadar fazla etkileneceği düşünülmemektedir.

Bundan sonraki çalışmalar COVID-19'un Türkiye'deki diğer finansal piyasalar üzerindeki etkisini/etkilerini belirlemek üzere gerçekleştirilebilir. Ayrıca diğer oynaklık hesaplama yöntemleri kullanılarak COVID-19'un Türkiye finansal piyasaları üzerindeki etkisini/etkilerini araştırmak için de çalışmalar gerçekleştirilebilir. Bu çalışmada elde edilen bulguların yatırımcılara, portföy yöneticilerine, akademisyenlere ve politika yapıcılara COVID-19'un Türkiye hisse senedi piyasası üzerindeki etkisi ve piyasanın güncel durumu hakkında önemli bilgiler sağlayacağı düşünülmektedir. 


\section{Introduction}

The Novel Coronavirus (COVID-19), which appeared in December 2019 in the city of Wuhan in Hubei province of China, quickly spread across the World. The World Health Organization declared COVID-19 as a global pandemic on March 11, 2020, and directed countries to take strict measures to control the COVID-19 outbreak (Göker, Eren, \& Karaca, 2020: 15). Although countries take strict measures against COVID-19, the spread of COVID19 among people has not been stopped yet. As of 8 July 2020, COVID-19 has been seen in 215 countries, 11,973,641 cases have been detected, and 547,120 people died worldwide (https://www.worldometers.info/coronavirus). For Turkey, the first case of COVID-19 was announced by Ministry of Health in Turkey on March 11, 2020. From March 11, 2020 until July 8, 2020, 207,897 cases have been detected, and 5,260 people died in Turkey (https://covid19.saglik.gov.tr). The COVID-19 outbreak has affected not only the health of people but also the economies of the countries negatively. Limited and restricted countries' borders due to COVID-19 have slowed down global economic activities. Most importantly, panic seen among companies, investors and consumers has distorted usual consumption patterns and also created some market anomalies. Financial markets of countries have also been responsive to the changes and countries' stock indices have plunged (McKibbin and Fernando, 2020: 2).

There are recent empirical studies that investigate economic and financial effects of COVID-19. Alber (2020) investigates the effects of COVID-19 spread on stock markets for China, France, Germany, Italy, Spain, and the United States. He finds that returns of the stock market are more sensitive to COVID-19 cumulative cases than cumulative or new deaths and new cases. He also reports that COVID-19 does not have the negative effect on stock market returns for Italy and United States. The economic effects of COVID-19 on China and the World are reported by Ayittey, Ayittey, Chiwero, Kamasah, \& Dzuvor (2020). Baker, Bloom, Davis, Kost, Sammon, \& Viratyosin (2020) examine the US stock market reaction to COVID-19. They report that the volatility of the US stock market returns jumped due to COVID-19 outbreak. Cinel (2020) focuses on global macroeconomic impacts of COVID-19. She reports the potential global economic costs of COVID-19 with some possible scenarios. Estrada, Park, Koutronas, Khan, \& Tahir (2020) empirically assess the effect of COVID-19 on the Chinese trade and financial markets. Göker et al. (2020) analyze the effect of COVID-19 on sector index returns for Turkey. They find that the returns of Sports, Tourism and Transportation sectors are effected more than the other sector index returns during COVID-19 pandemic. The influence of COVID19 on stock markets for China, Italy, Spain, Turkey, the United Kingdom, and the United States is examined by Gunay (2020). He reports that Chinese and Turkish stock markets co-movement increased more than the other stock markets co-movements due to contagious effects of COVID-19. K1lıç (2020) investigates the effect of COVID-19 on Borsa İstanbul sector returns. He finds that many Borsa İstanbul sectors have negative abnormal returns. He also finds that while tourism and textile sectors have the highest negative abnormal returns, the trade sector has positive abnormal returns. Luo and Tsang (2020) estimate on the economic impact of COVID-19 on China and the global economy. McKibbin and Fernando (2020) investigate global macroeconomic impacts of COVID-19 with seven scenarios. They report that COVID19 outbreak could significantly impact the global economy only in the short run and future costs of COVID-19 might be avoided by greater investment in public health systems. The impact of COVID-19 on financial markets for China and the USA is reported by Sansa (2020). Sar1 and Kartal (2020) show the effect of COVID-19 on gold prices and VIX index. The changes occurring in the macroeconomic indicators specified in Turkey's economy is examined by Soylu (2020). He reports that COVID-19 has directly affected sectoral confidence indices, Foreign Trade Statistics, labour market, Industrial Production Index and tourism revenues in 
the Turkish economy. Şit and Telek (2020) investigate the impacts of COVID-19 on gold ounce prices and the dollar index. According to the cointegration and causality tests, they find that the cointegration relationship has between the number of COVID-19 deaths and cases and the dollar index and that positive shocks in the number COVID-19 cases and deaths cause shocks on the dollar index and gold ounce price. Yan (2020) examines how Chinese stock markets react to COVID-19. He finds that stock prices in the Chinese stock markets fall sharply due to COVID-19 pancemic. Zeren and Hizarc1 (2020) examine the possible effects of COVID-19 on stock markets for China, France, Germany, Italy, South Korea, and Spain. They report that all stock markets are cointegrated with the COVID-19 total death numbers.

The existing literature provides some useful information about the effects of COVID19 pandemic on stock returns for Turkey; however, almost nothing is known about the effects of COVID-19 pandemic on stock volatilities, which is often identified as a measure of uncertainty and also one of the most important indicators for not only investment and portfolio management decisions but also option pricing and financial market regulation (Balcilar, Gupta, \& Kyei, 2018: 74; Poon and Granger, 2003: 478), for Turkey. Therefore, in this paper, the effect of COVID-19 outbreak on Turkey stock market is investigated with montly realized volatility, which frequently used in the empirical finance literature (see for example, Kambouroudis, McMillan, \& Tsakou (2016); Suleman, Gupta, \& Balcilar (2017); Apergis, Bonato, Gupta, \& Kyei (2018); Balcilar et al. (2018); Gkillas, Gupta, \& Wohar (2018); Bouri, Demirer, Gupta, \& Marfatia (2019); Demirer, Gkillas, Gupta, \& Pierdzioch (2019); Balcilar, Gupta, Wang, \& Wohar (2020)) to determine the volatilities of financial assets, values of 23 primary sector indices traded on Borsa İstanbul. This paper contributes to the literature in at least five important ways: First, this paper is one of the first to examine the effect of COVID-19 pandemic on the Turkish stocks volatilities. Second, this paper shows which of the primary sector indices traded on Borsa İstanbul are more effected by COVID-19. Third, this paper demonstrates the primary sector index traded on Borsa İstanbul, which is least effected by COVID-19. Fourth, this paper provides information about the period when COVID-19 effected the Turkish stock market. Fifth, this paper contributes to the recently emerging literature which examines the effect of COVID-19 pandemic on financial markets.

The rest of the paper is organized as follows: Section 2 presents some information about the methodology and the data, while Section 3 reports and discusses the empirical results. Section 4 includes the robustness analysis. Finally, Section 5 concludes the paper.

\section{Data and Methodology}

In this paper, one-year data of 23 primary sector indices traded on Borsa İstanbul are used for analysis. Primary sector indices daily data are downloaded from the database of www.investing.com for a period of June 7, 2019 to July 6, 2020, with a total of 270 observations for each index. Primary sector indices used in the paper are given in Table 1.

Table 1: Primary Sector Indices

\begin{tabular}{llll}
\hline Index Name & Code & Index Name & Code \\
\hline 1. Banks & XBANK & 13. Non-Metal Mineral Product & XTAST \\
\hline 2. Basic Metal & XMANA & 14. Real Estate Invest Trusts & XGMYO \\
\hline 3. Chem Petrol Plastic & XKMYA & 15. Services & XUHIZ \\
\hline 4. Electricity & XELKT & 16. Sports & XSPOR \\
\hline
\end{tabular}




\begin{tabular}{llll}
\hline 5. Financials & XUMAL & 17. Technology & XUTEK \\
\hline 6. Food Beverage & XGIDA & 18. Telecommunication & XILTM \\
\hline 7. Holding \& Investments & XHOLD & 19. Textile Leather & XTEKS \\
\hline 8. Industrials & XUSIN & 20. Tourism & XTRZM \\
\hline 9. Information Technology & XBLSM & 21. Transportation & XULAS \\
\hline 10. Insurance & XSGRT & 22. Wholesale \& Retail Trade & XTCRT \\
\hline 11. Leasing Factoring & XFINK & 23. Wood Paper Printing & XKAGT \\
\hline
\end{tabular}

12. Metal Products Machinery XMESY

In order to calculate the realized volatility of sector indices, first daily returns are calculated as:

$$
r_{t}=\ln \left(p_{t} / p_{t-1}\right) \times 100
$$

where $p_{t}$ is the closing value of the index on day $t$ and $\ln ()$ the natural logarithm. After the daily returns of the sector indices are calculated, monthly realized volatilities, i.e. the sum of squared daily returns over the number of trading days in a month as suggested in Andersen and Bollerslev (1998), are calculated as:

$$
R V_{t}=\sum_{i=1}^{M} y_{t, i}^{2}
$$

where $y_{t, i}$ is the daily $M x 1$ return vector and $i=1, \ldots, M$ the number of daily returns. Generalized Autoregressive Conditional Heteroskedasticity (GARCH) model are also used to calculate the volatility of financial assets in the literature (see for example, Sadorsky (2006); Ben Nasr, Lux, Ajmi, \& Gupta (2016); Demirer, Gupta, Suleman, \& Wohar (2018); Gupta and Yoon (2018)). Since GARCH model are linear in nature, it does not take into account nonlinearity, often seen in financial time series, while capturing the volatility (Balcilar, Bouri, Gupta, \& Roubaud, 2017). To test for nonlinearity in the daily return series used in this study, the BDS test of Broock, Dechert, Scheinkman, \& LeBaron (1996) is employed with 10,000 bootstrap replications. Table 2 exhibit the results of the BDS test of nonlinearity.

Table 2: BDS Test of Nonlinearity

\begin{tabular}{lccccc}
\hline \multirow{2}{*}{ Return Series } & \multicolumn{5}{c}{ Dimension } \\
\cline { 2 - 6 } & $\mathbf{2}$ & $\mathbf{3}$ & $\mathbf{4}$ & $\mathbf{5}$ & $\mathbf{6}$ \\
\hline XBANK & 1.241 & 1.570 & $2.489^{* * *}$ & $3.266^{* * *}$ & $4.010^{* * *}$ \\
\hline XMANA & 1.444 & $2.797^{* *}$ & $3.740^{* * *}$ & $4.754^{* * *}$ & $5.281^{* * *}$ \\
\hline XKMYA & $3.773^{* * *}$ & $5.094^{* * *}$ & $5.502^{* * *}$ & $6.013^{* * *}$ & $6.623^{* * * *}$ \\
\hline XELKT & $4.345^{* * *}$ & $4.944^{* * *}$ & $5.480^{* * *}$ & $6.047^{* * *}$ & $6.396^{* * *}$ \\
\hline XUMAL & 1.110 & 1.454 & $2.602^{* *}$ & $3.432^{* * *}$ & $3.982^{* * *}$ \\
\hline XGIDA & 1.330 & $2.239^{* *}$ & $2.939^{* * *}$ & $3.566^{* * *}$ & $3.751^{* * *}$ \\
\hline
\end{tabular}




\begin{tabular}{|c|c|c|c|c|c|}
\hline XHOLD & $4.802^{* * *}$ & $5.230^{* * *}$ & $5.859^{* * *}$ & $6.534^{* * *}$ & $6.949^{* * *}$ \\
\hline XUSIN & $2.915^{* * *}$ & $3.965^{* * *}$ & $4.835^{* * *}$ & $5.793^{* * *}$ & $6.152^{* * *}$ \\
\hline XBLSM & $7.690^{* * *}$ & $7.635^{* * *}$ & $8.265^{* * *}$ & $9.457^{* * *}$ & $10.754^{* * *}$ \\
\hline XSGRT & $4.256^{* * *}$ & $5.591^{* * * *}$ & $5.555^{* * *}$ & $6.370^{* * *}$ & $6.986^{* * *}$ \\
\hline XFINK & $5.835^{* * *}$ & $6.976^{* * *}$ & $7.729^{* * *}$ & $8.212^{* * *}$ & $8.790^{* * *}$ \\
\hline XMESY & $3.977^{* * *}$ & $4.960^{* * *}$ & $5.575^{* * *}$ & $6.371^{* * *}$ & $6.807^{* * *}$ \\
\hline XTAST & $4.280^{* * *}$ & $5.013^{* * *}$ & $5.117^{* * *}$ & $5.042^{* * *}$ & $5.403^{* * *}$ \\
\hline XGMYO & $5.063^{* * *}$ & $5.739^{* * *}$ & $5.750^{* * *}$ & $6.515^{* * *}$ & $6.606^{* * *}$ \\
\hline XUHIZ & 0.237 & $2.278^{* *}$ & $3.061^{* * *}$ & $3.324^{* * *}$ & $3.733^{* * *}$ \\
\hline XSPOR & $8.865^{* * *}$ & $10.662^{* * * *}$ & $11.545^{* * *}$ & $12.230^{* * * *}$ & $12.792^{* * *}$ \\
\hline XUTEK & $2.672^{* *}$ & $3.318^{* * *}$ & $3.674^{* * *}$ & $4.092^{* * *}$ & $4.251^{* * *}$ \\
\hline XILTM & 1.683 & $2.654^{* *}$ & $3.062^{* * *}$ & $3.584^{* * *}$ & $3.968^{* * *}$ \\
\hline XTEKS & $5.719^{* * *}$ & $6.704^{* * *}$ & $7.589^{* * *}$ & $8.415^{* * *}$ & $9.203^{* * *}$ \\
\hline XTRZM & $5.501^{* * *}$ & $6.577^{* * *}$ & $7.056^{* * *}$ & $8.018^{* * *}$ & $9.151^{* * *}$ \\
\hline XULAS & $6.631^{* * *}$ & $7.016^{* * *}$ & $7.670^{* * *}$ & $8.370^{* * *}$ & $8.884^{* * *}$ \\
\hline XTCRT & $6.598^{* * *}$ & $8.007^{* * *}$ & $8.695^{* * *}$ & $8.828^{* * *}$ & $9.323^{* * *}$ \\
\hline XKAGT & $5.742^{* * * *}$ & $6.757^{* * *}$ & $7.089^{* * * *}$ & $8.032^{* * *}$ & $8.782^{\text {**** }}$ \\
\hline
\end{tabular}

Note: Value in cell represents BDS $z$-statistic; ${ }^{* *}$ and ${ }^{* * *}$ indicates rejection of the null hypothesis that the return series independently and identically distributed (i.i.d.) at $5 \%$ and $1 \%$ level of significance, respectively.

As shown in Table 2, the null hypothesis of linearity is rejected at 1 percent level of significance for all daily return series across various dimensions, providing strong evidence of nonlinearity in the return series. This evidence indicates that, volatility values are more reliable based on squared returns i.e. realized volatilities than GARCH model.

The summary statistics of realized volatilities of primary sector indices used in the paper have been provided in Table 3 .

Table 3: Summary Statistics

\begin{tabular}{llllllllll}
\hline \multirow{2}{*}{ Indices } & \multicolumn{7}{c}{ Statistic } \\
\cline { 2 - 9 } & Mean & Med. & Max. & Min. & S.D. & Skew. & Kurt. & J-B. & p-values \\
\hline XBANK & 0.962 & 0.748 & 3.997 & 0.128 & 0.982 & 2.205 & 7.684 & 24.141 & 0.000 \\
\hline XMANA & 0.592 & 0.487 & 2.377 & 0.189 & 0.542 & 2.750 & 9.789 & 44.535 & 0.000 \\
\hline XKMYA & 0.539 & 0.351 & 2.934 & 0.059 & 0.715 & 2.928 & 10.461 & 52.481 & 0.000 \\
\hline
\end{tabular}




\begin{tabular}{|c|c|c|c|c|c|c|c|c|c|}
\hline XELKT & 0.842 & 0.462 & 4.461 & 0.136 & 1.105 & 2.739 & 9.597 & 42.889 & 0.000 \\
\hline XUMAL & 0.694 & 0.491 & 3.414 & 0.115 & 0.841 & 2.602 & 9.127 & 37.700 & 0.000 \\
\hline XGIDA & 0.677 & 0.477 & 3.300 & 0.100 & 0.802 & 2.721 & 9.546 & 42.271 & 0.000 \\
\hline XHOLD & 0.588 & 0.338 & 3.323 & 0.120 & 0.822 & 2.886 & 10.171 & 49.427 & 0.000 \\
\hline XUSIN & 0.437 & 0.214 & 2.838 & 0.105 & 0.704 & 3.122 & 11.216 & 62.126 & 0.000 \\
\hline XBLSM & 1.367 & 0.794 & 7.806 & 0.180 & 1.975 & 2.687 & 9.411 & 40.825 & 0.000 \\
\hline XSGRT & 0.350 & 0.152 & 1.997 & 0.028 & 0.504 & 2.735 & 9.517 & 42.232 & 0.000 \\
\hline XFINK & 2.001 & 1.638 & 9.720 & 0.136 & 2.369 & 2.648 & 9.425 & 40.446 & 0.000 \\
\hline XMESY & 0.573 & 0.298 & 3.712 & 0.089 & 0.925 & 3.075 & 11.000 & 59.397 & 0.000 \\
\hline XTAST & 0.801 & 0.612 & 3.959 & 0.132 & 0.939 & 2.968 & 10.650 & 54.670 & 0.000 \\
\hline XGMYO & 0.763 & 0.395 & 4.469 & 0.077 & 1.113 & 2.889 & 10.221 & 49.890 & 0.000 \\
\hline XUHIZ & 0.430 & 0.266 & 2.509 & 0.096 & 0.611 & 3.085 & 11.086 & 60.348 & 0.000 \\
\hline XSPOR & 3.289 & 1.739 & 15.670 & 0.273 & 4.550 & 1.894 & 5.298 & 11.450 & 0.000 \\
\hline XUTEK & 1.040 & 0.623 & 5.456 & 0.021 & 1.341 & 2.777 & 9.797 & 44.951 & 0.000 \\
\hline XILTM & 0.747 & 0.462 & 3.047 & 0.107 & 0.730 & 2.377 & 8.249 & 29.256 & 0.000 \\
\hline XTEKS & 0.924 & 0.402 & 6.274 & 0.122 & 1.578 & 3.060 & 10.967 & 58.884 & 0.000 \\
\hline XTRZM & 1.525 & 0.767 & 8.822 & 0.132 & 2.259 & 2.630 & 9.068 & 37.616 & 0.000 \\
\hline XULAS & 1.312 & 0.782 & 7.080 & 0.093 & 1.791 & 2.599 & 8.978 & 36.603 & 0.000 \\
\hline XTCRT & 0.588 & 0.294 & 3.412 & 0.127 & 0.852 & 2.879 & 10.052 & 48.344 & 0.000 \\
\hline XKAGT & 0.979 & 0.516 & 5.852 & 0.107 & 1.477 & 2.798 & 9.871 & 45.810 & 0.000 \\
\hline
\end{tabular}

Note: Med., Max., Min., S.D., Skew., Kurt., and J-B. stands for median, maximum, minimum, standard deviation, skewness, kurtosis, and Jarque-Bera, respectively. p-values are the probability values of the Jarque-Bera normality test.

Mean values in Table 3 show that Sports Index has the highest average monthly realized volatility with $3.289 \%$, while Insurance Index has the least average monthly realized volatility with $0.350 \%$. In terms of standard deviation, Sports Index has the highest standard deviation with $4.55 \%$ and Insurance Index has the least standard deviation with $0.504 \%$. Skewness values indicates that the distribution of realized volatilities of all primary sector indices skewed to the right relative to the normal distribution. According to the kurtosis values, the distribution of realized volatilities of each primary sector indices has fat tails relative to the normal distribution. In short, Skewness and Kurtosis values state that monthly realized volatility distributions belonging to primary sector indices are deviated from the normality distribution. The deviation from the normality distribution can be also observed with the p-values of the Jarque-Bera normality test. 


\section{Empirical Results}

Figure 1 shows time series plots of monthly realized volatilities calculated for each primary sector indices used in this paper to examine the impact of COVID-19 on Turkey stock market. Time series plots in Figure 1 shows that there are significant volatility jump for all sectors in March 2020 when the first cases seen in Turkey and when the World Health Organization declared the COVID-19 as a pandemic. While the sector most affected by COVID-19 with $15.7 \%$ volatility jump is the sports sector, the sector least affected by the COVID-19 with $2 \%$ volatility jump is the insurance sector. Leasing Factoring, Tourism, Information Technology, Transportation, and Textile Leather sectors are also more affected by COVID-19 than other sectors. Realized volatilities in Figure 1 also shows that after March 2020, Turkey stock marked back to normal and the effect of COVID-19 on the market has disappeared. Although it is expected that there will be a second wave related to COVID-19, it is not thought that Turkey stock market's response to the virus will be so high.
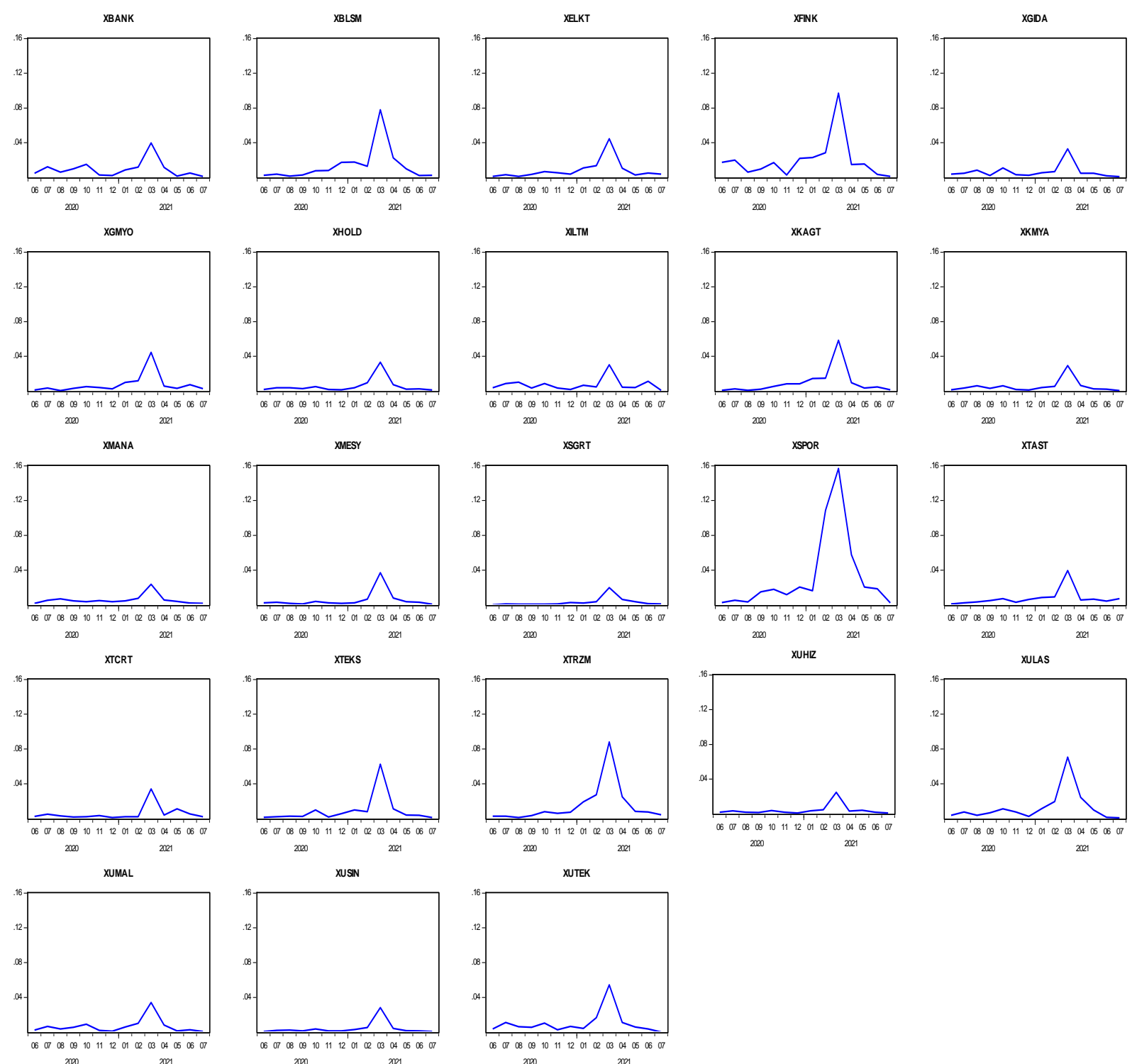

Figure 1: Monthly Realized Volatilities 


\section{Robustness Check}

For the robustness check of the findings obtained in this study, following the literature (e.g., Ben Nasr et al., 2016; Bouri et al., 2019; Demirer et al., 2019), another measure of volatility i.e., GARCH-based volatility, is used. Although it is stated in previous sections that realized volatility is better suited to the return series in this study, it is thought that GARCHbased volatility may be suitable for robustness check of the findings obtained from realized volatility. Monthly GARCH-based volatility of the primary sector indices is obtanined as a standard deviation from GARCH $(1,1)$ model. The basics of the model is as follows:

$$
\begin{aligned}
& y_{t}=\mu+\varepsilon_{t} \\
& h_{t}=\omega+a \varepsilon_{t-1}^{2}+\beta h_{t-1}
\end{aligned}
$$

where $y_{t}$ denotes the sector indices returns, $h_{t}$ the conditional variance, $\omega$ the mean volatility level, $\varepsilon_{t-1}^{2}$ the lagged error, $h_{t-1}$ the lagged conditional variance, and $\varepsilon_{t}$ the stochastic disturbance term that is assumed to be normally distributed with zero mean.

Monthly GARCH-based volatilities of the primary sector indices are plotted in Figure 2. It can be easily seen that the volatility jump of the sports sector (insurance sector) due to the COVID-19 pandemic is quite high (low) relative to the other primary sector indices. These results robust the findings of the study.

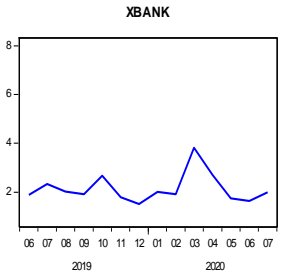

xGMvo

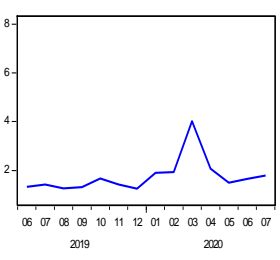

XMANA

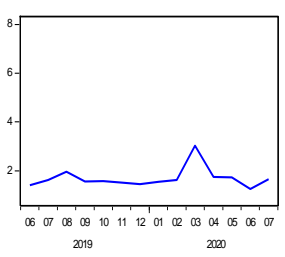

XTCRT

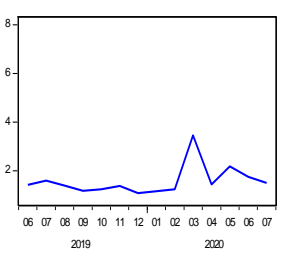

XUMAL

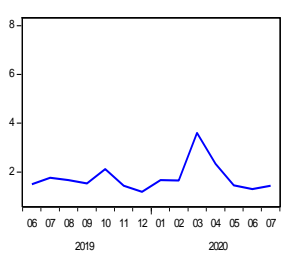

XBLSI

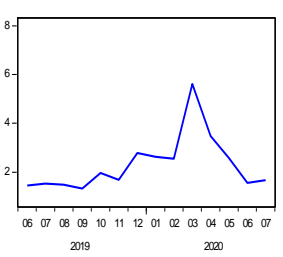

XHOLD

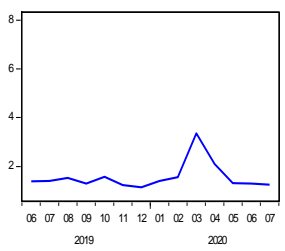

XMESY

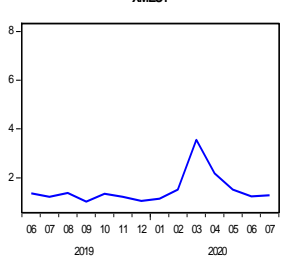

XTEKS

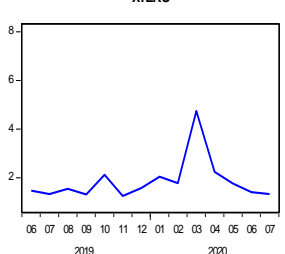

XUSI

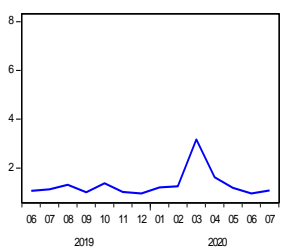

XELKT

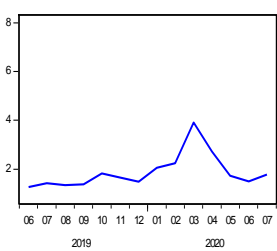

XLTM

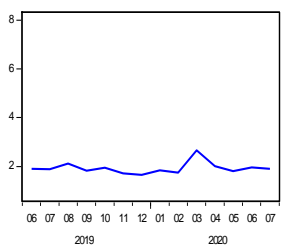

XSGRT

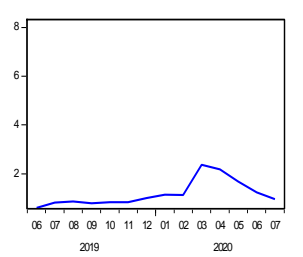

XTRZM

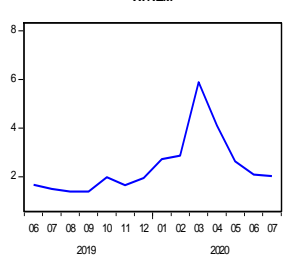

XUTE

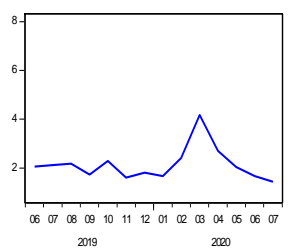

XFNK

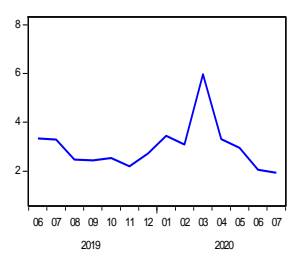

XKAGT

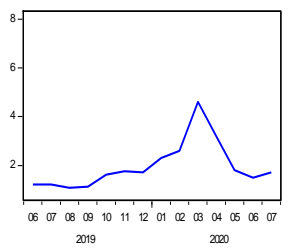

XSPOR

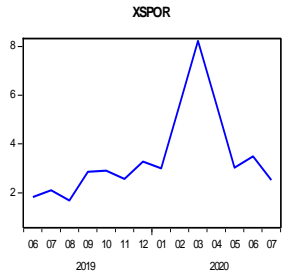

XHHZ

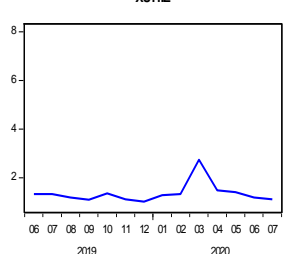

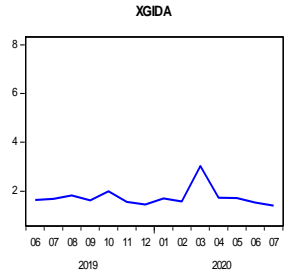

XKMYA

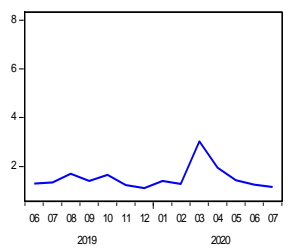

XTAST

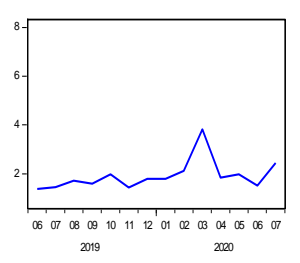

XULAS

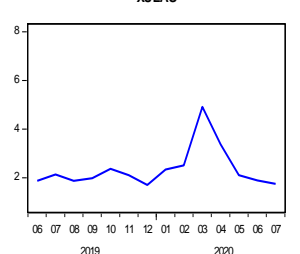

2020

Figure 2: Monthly GARCH-Based Volatilities 


\section{Conclusion}

In this paper, monthly realized volatilities of 23 primary sector indices traded on Borsa İstanbul are used to investigate the effect of COVID-19 on Turkey stock market. Monthly realized volatilities of indices demonstrate that: (1) Volatility jumps for all sector indices occurred in March 2020, when COVID-19 emerged in Turkey and spread rapidly; (2) Sports sector is the most affected sector in Turkey from COVID-19; (3) The sector least affected by COVID-19 in Turkey is the Insurance sector; (4) In Turkey, COVID-19 were affected Leasing Factoring, Tourism, Information Technology, Transportation, and Textile Leather sectors more than other sectors used in the paper; (5) The impact of COVID-19 on Turkey stock market disappeared after March 2020; (6) Turkey stock market returns to normal after March 2020. These findings are robusted with another important volatility measure, GARCH-based volatility. Further studies can be carried out investigating the effect of COVID-19 on other financial markets in Turkey. In addition, studies can be carried out examining the impact of COVID-19 on Turkey financial markets using other volatility calculation methods.

\section{References}

Alber, N. (2020). The effect of coronavirus spread on stock markets. The case of the worst 6 countries, http://ssrn.com/abstract=3578080.

Andersen, T. G. \& Bollerslev, T. (1998). Answering the skeptics: Yes, standard volatility models do provide accurate forecasts. International Economic Review, 39, 885-905.

Apergis, N., Bonato, M., Gupta, R. \& Kyei, C. (2018). Does geopolitical risks predict stock returns and volatility of leading defense companies? Evidence from a nonparametric approach. Defence and Peace Economics, 29(6), 684-696.

Ayittey, F. K., Ayittey, M. K., Chiwero, N. B., Kamasah, J. S. \& Dzuvor, C. (2020). Economic impacts of Wuhan 2019-nCoV on China and the World. Journal of Medical Wirology, 92, 473-475.

Baker, S. R., Bloom, N., Davis, S. J., Kost, K. J., Sammon, M. C. \& Viratyosin, T. (2020). The unprecedented stock market impact of COVID-19. https://www.nber.org/papers/w26945.

Balcilar, M., Gupta, R. \& Kyei, C. (2018). Predicting stock returns and volatility with investor sentiment indices: A reconsideration using a nonparametric causality-in-quantiles test. Bulletin of Economic Research, 70(1), 74-87.

Balcilar, M., Gupta, R., Wang, S. \& Wohar, M. E. (2020). Oil price uncertainty and movements in the US government bond risk premia. North American Journal of Economics and Finance, 52, 101147.

Balcilar, M., Bouri, E., Gupta, R. \& Roubaud, D. (2017). Can volume predict Bitcoin returns and volatility? A quantiles-based approach. Economic Modelling, 64, 74-81.

Ben Nasr, A., Lux, T., Ajmi, A. N. \& Gupta, R. (2016). Forecasting the volatility of the Dow Jones Islamic stock market index: Long memory vs. regime switching. International Review of Economics and Finance, 45(1), 559-571.

Bouri, E., Demirer, R., Gupta, R. \& Marfatia, H. A. (2019). Geopolitical risks and movements in Islamic bond and equity markets: A Note. Defence and Peace Economics, 30(3), 367379.

Broock, W. A., Dechert, W., Scheinkman, J. A. \& LeBaron, B. (1996). A test for independence based on the correlation dimension. Econometric Review, 15(3), 197-235. 
Cinel, E. A. (2020). Covid-19'un küresel makroekonomik etkileri ve beklentiler. Politik Ekonomik Kuram, 4(1), 124-140.

Demirer, R., Gkillas, K., Gupta, R. \& Pierdzioch, C. (2019). Time-varying risk aversion and realized gold volatility. North American Journal of Economics and Finance, 50, 101048.

Demirer, R., Gupta, R., Suleman, T. \& Wohar, M. E. (2018). Time-varying rare disaster risks, oil returns and volatility. Energy Economics, 75, 239-248.

Estrada, M. A. R., Park, D., Koutronas, E., Khan, A. \& Tahir, M. (2020). The impact of infectious and contagious diseases and its impact on the economic performance: The case of Wuhan, China. https://ssrn.com/abstract=3527330.

Gkillas, K., Gupta, R. \& Wohar, M. E. (2018). Volatility jumps: The role of geopolitical risks. Finance Research Letters, 27, 247-258.

Göker, İ. E. K., Eren, B. S. \& Karaca, S. S. (2020). The impact of the COVID-19 (Coronavirus) on the Borsa Istanbul sector index returns: An event study. Gaziantep University Journal of Social Sciences, 2020 Special Issue, 14-41.

Gunay, S. (2020). A new form of financial contagion: Covid-19 and stock market responses, http://ssrn.com/abstract=3585069.

Gupta, R. \& Yoon, S-M. (2018). OPEC news and predictability of oil futures returns and volatility: Evidence from a nonparametric causality-in-quantiles approach. The North American Journal of Economics and Finance, 45, 206-214.

https://covid19.saglik.gov.tr, Date of Access: 8 July 2020

https://www.investing.com, Date of Access: 6 July 2020

https://www.worldometers.info/coronavirus, Date of Access: 8 July 2020

Kambouroudis, D. S., McMillan, D. G. \& Tsakou, K. (2016). Forecasting Stock Return Volatility: A Comparison of GARCH, Implied Volatility, and Realized Volatility Models. The Journal of Futures Markets, 36(12), 1127-1163.

Kilıç, Y. (2020). Borsa İstanbul'da COVID-19 (Koronavirüs) etkisi. Journal of Emerging Economies and Policy, 5(1), 66-77.

Luo, S. \& Tsang, K. P. (2020). China and World output impact of the Hubei lockdown during the coronavirus outbreak. https://ssrn.com/abstract=3543760.

McKibbin, W. J. \& Fernando, R. (2020). The global macroeconomic impacts of COVID-19: Seven scenarios. https://ssrn.com/abstract $=3547729$.

Poon, S-H. \& Granger, C. W. J. (2003). Forecasting volatility in financial markets: A review. Journal of Economic Literature, 41(2), 478-539.

Sadorsky, P. (2006). Modeling and forecasting petroleum futures volatility. Energy Economics, 28(4), 467-488.

Sansa, N. A. (2020). The impact of Covid-19 on the financial markets. Evidence from China and USA, http://ssrn.com/abstract=3562530.

Sarı, S. S. \& Kartal, T. (2020). COVID-19 salgınının altın fiyatları, petrol fiyatları ve VIX endeksi ile arasındaki ilişki. Erzincan Üniversitesi Sosyal Bilimler Enstitüsü Dergisi, 13(1), 93-109. 
Soylu, Ö. B. (2020). Türkiye ekonomisinde COVID-19'un sektörel etkileri. Avrasya Sosyal ve Ekonomi Araştırmaları Dergisi, 7(5), 169-185.

Suleman, T., Gupta, R. \& Balcilar, M. (2017). Does country risks predict stock returns and volatility? Evidence from a nonparametric approach. Research in International Business and Finance, 42, 1173-1195.

Şit, A. \& Telek, C. (2020). Covid-19 pandemisinin altın ons fiyatı ve dolar endeksi üzerine etkileri. Gaziantep University Journal of Social Sciences, 2020 Special Issue, 1-13.

Yan, C. (2020). COVID-19 Outbreak and stock prices: Evidence from China, http://ssrn.com/abstract=3574374.

Zeren, F. \& Hizarc1, A. E. (2020). The impact of Covid-19 coronavirus on stock markets. Evidence from selected countries. Muhasebe ve Finans Incelemeleri Dergisi, 3(1), 7884. 